\title{
Iodine Content of Salt in Retail Shops and Retailers' Knowledge on Iodized Salt in Wa East District, Upper West Region, Ghana
}

\author{
Prince Kubi Appiah (D), ${ }^{1}$ Georgina Agartha Fenu, ${ }^{2}$ and Francis Wadga-Mieza Yankey ${ }^{3}$ \\ ${ }^{1}$ Department of Family and Community Health, School of Public Health, University of Health and Allied Sciences, Ho, Ghana \\ ${ }^{2}$ Department of Epidemiology and Biostatistics, School of Public Health, University of Health and Allied Sciences, Ho, Ghana \\ ${ }^{3}$ Academic Affairs Directorate, University of Health and Allied Sciences, Ho, Ghana
}

Correspondence should be addressed to Prince Kubi Appiah; appiahkubiprince23@yahoo.com

Received 12 February 2020; Revised 15 May 2020; Accepted 22 May 2020; Published 5 June 2020

Academic Editor: Elena Gonz lez Fandos

Copyright (c) 2020 Prince Kubi Appiah et al. This is an open access article distributed under the Creative Commons Attribution License, which permits unrestricted use, distribution, and reproduction in any medium, provided the original work is properly cited.

\begin{abstract}
Background. There are laws to enforce the universal iodization of salt to check the consequences of iodine deficiency in Ghana. These laws are to ensure that there are production and sales of iodized salt in the country. Yet, the availability of iodized salt in the county's households is still not encouraging, with data indicating that $93.8 \%$ of children have urine iodine $<100 \mu \mathrm{g} / \mathrm{dl}$. Hence, the study investigated the iodine content of salt in retail shops and knowledge of iodized salt among retailers in the Wa East District. The study will help the informed decision on strengthening and enforcing laws to achieve the universal salt iodization and the consumption of adequate iodized salt. Method. The study was a descriptive cross-sectional survey. We used a questionnaire to collect quantitative data from participants and a rapid field test kits to determine the iodine content of salt. STATA version 14.2 was used to analyse data. Chi-squared and logistic regression models were used to examine the association between the dependent and independent variables and considered $p$ value $<0.05$ as statistically significant. Findings. The retailers' primary source of information about iodized salt was health workers (46.2\%), with the majority (52.8\%) of them having low knowledge of iodized salt. Notwithstanding the high knowledge of iodized salt, as high as $53.8 \%$ of the salts do not have adequate iodine $(<15 \mathrm{ppm})$. Retailer's sex $(p=0.014)$, educational level $(p=0.006)$, primary source of information about iodized salt $(p=0.012)$, texture of salt being sold ( $p=0.023)$, and mode of displaying salt in the shop $(p=0.003)$ were associated with knowledge of iodised salt. Again, retailer's educational level $(p=0.036)$, knowledge of iodized salt $(p=0.034)$, texture of salt being sold $(p=0.021)$, and method of displaying the salt being sold $(p=0.004)$ were associated with an iodine content of the salt in the shop. Conclusions. Though policies have been implemented to promote production and consumption of iodized salt, the iodine content of salt in retail shops in the Wa East are not encouraging. We recommend the establishment of checkpoints along the production and distribution chain to ensure salt with adequate iodine reaches the consumer. Again, traders of iodized salt should have regular training on ways to preserve salt to maintain its iodine content.
\end{abstract}

\section{Background}

Iodized Salt has been credited with preventing about 750 million cases of goitre over the past years, with Iodine Global Network and UNICEF estimating that globally about 6.1 billion people are currently consuming iodised salt representing a significant achievement of large-scale food fortification [1]. However, studies in Tunisia and Tanzania showed that salt in wholesale and retail shops are inadequately iodised $[2,3]$.
Ghana has, since 1996, passed laws, including the Food and Drugs (Amendment) Act 523, the Provisional National Defence Council Law (PNDCL) 3058, and the Public Health Act 851 aimed at promoting universal salt iodization to check the consequences of iodine deficiency. Despite this, studies in the country indicate that $93.8 \%$ of children have low urine iodine $(<100 \mu \mathrm{g} / \mathrm{dl})$ levels [4] and $36.6 \%$ of women are living in households with no iodized salt [5]. Again, a study conducted in the Volta Region of Ghana revealed that only $30.9 \%$ and $24.5 \%$ of salt in the retail shops and 
households, respectively, have adequate iodine (>15 ppm) [6]. Also, iodine concentration levels in salt in retail shops in Accra do not meet the standards of the Ghana Standard Authority [7]. Though Volta Region and Accra are closer to the iodized salt production sites, transporting iodized salts to these areas might have less effect on iodine content than to the Wa East District.

Aware of the consequences of iodine deficiency on the general population, especially women and children including abortion, miscarriage, brain damage, congenital abnormalities, and perinatal deaths [5], we investigated the iodine content of salt in retail shops and knowledge of iodized salt among retailers in the Wa East District to help inform the decision on strengthening and enforcing laws to achieve the universal salt iodization and the consumption of adequate iodized salt.

\section{Materials and Methods}

2.1. Study Site. The total land size of Wa East District is about $4,279.1 \mathrm{~km}^{2}$, forming approximately $17.3 \%$ of the total landmass of the Upper West Region. It is located in the South-Eastern part of the region and has one-hundred and forty-five (145) communities that are completely rural with no urban settlements. The district had an estimated population of eighty-nine thousand one-hundred and eightytwo $(89,182)$ with an annual fertility rate of 3.9 and crude birth rate (CBR) of 25 per 1,000 populations. Males constitute $50.5 \%$, while females represent $49.5 \%$. The distance between the study area and salt production sites on the coast of Ghana is about $713.1 .3 \mathrm{~km}$. About $68.6 \%$ of the people who are 11 years or older are uneducated, with the proportion of females (53.4\%) higher than that of males $(46.6 \%)$. About $76.0 \%$ of the people who are 15 years or older are economically active, while $24.0 \%$ are not active. Of the economically active ones, $97.8 \%$ of them are employed while $2.2 \%$ are unemployed [8]. There are nine health centres, a clinic, and twenty-eight Community-Based Health Planning and Services (CHPS) compounds providing healthcare services to the people in the district. The area also has some secondary and elementary schools providing formal education to people in the area including two senior high secondary schools, fifty-four junior high secondary schools, eighty-one primary schools, and seventy-seven nursery schools [9].

2.2. Study Population. The study involves retailers of salt who had stayed in the district for three or more months. However, only those who signed informed consent forms were allowed to participate in the study. Foreign nationals and severely ill people were excluded from the study.

2.3. Study Design. We used a descriptive cross-sectional study and a qualitative and quantitative data collection procedure to collect data on iodine concentration levels in salt in retail shops and knowledge of iodized salt among retailers in the district from October to November 2019.
2.4. Sample Size and Sampling Procedure. A total of 197 salt retail shops and retailers were involved in the study. A total population purposive sampling method was used to include all the 197 registered salt retail shops and retailers in the study area.

2.5. Data Collection Tools and Procedure. Semistructured questionnaires and the Rapid Field Iodine Test kits manufactured by MBI KITS INTERNATIONAL supplied to Ghana Health Service by UNICEF were the tools used to collect data on iodine concentration levels of salts in retail shops, knowledge on iodized salt, and demographic characteristics of the retailers. Face-to-face interview technique and collection of a sample of salt for the iodine test were the methods used to collect study data. The Rapid Field Iodine Test kits used were part of kits tested and approved for Ghana Health Service to use for routine services by the Ghana Standard Board and Food and Drugs Authority.

Iodine concentration levels of salt in each retail shop were tested by adding two drops of the test solution to each sample using the Rapid Field Test kits and the testing procedure was followed as specified by the manufacturer of the kits. After sixty seconds, the colour of the salt was crosschecked with the colour chart of the kits to determine the iodine content.

A verification test was performed on salts that did not show colour change after sixty-seconds by adding five drops of the recheck solution and two drops of the test solution to a fresh sample as specified in the user instructions. When no colour change appeared after the retest, it was assumed and concluded that the salt does not contain iodine. Due to differences in an individual's eyesight and to reduce errors, two individuals were recruited to perform double iodine tests on each sample separately and independently.

Ages of the retailers were assessed using their Baptismal Certificates, Birth Certificates, Health Insurance Cards, Marriage Certificates, and events calendars for participants who do not possess any certificate or document.

2.6. Data Analysis. The statistical software STATA 14.2 version was used to analyse data and display them in tables and charts as frequencies and proportions to delineate the characteristics of the study population. Chi-squared and logistic regression analytical tests were used to investigate the associations between the predictor and outcome variables, and the $p$ value $<0.05$ was recognized as exhibiting significant association. The retailers' knowledge on iodized salt was appraised on 11 points, and those who scored 0 to 5 points were described as having low (poor) knowledge, while those who scored 6 to 11 points were described as having high (good) knowledge on iodized salt.

\section{Results}

3.1. Background Characteristics of Retailers. A total of onehundred and ninety-seven (197) salt retailers in Wa East District were involved in the study. The mean age of the retailers was 39.5 years $( \pm 2.6 \mathrm{sd})$, with a comparative 
majority $(47.2 \%)$ of them being 40 years or older. The majority $(63.5 \%)$ of them was females, and a comparative majority (45.2\%) of the salt retailers had no formal education. Again, the majority (73.1\%) of them was married, and $78.2 \%$ were Moslems. Also, a comparative majority (48.2\%) of them were Waalas. About $1 \%$ of the retailers' tested the salt for iodine content before purchasing from the wholesale shops and distributors. Fine-texture salt (38.1\%) was the comparative majority found in the shops in the district, while $44.2 \%$ of the retailers had placed salt directly under the Sun. About $37.6 \%$ of salts were in the original package from the producer (Table 1).

\subsection{Retailers' Primary Source of Information of Iodized Salt} and Knowledge on Iodized Salt. The primary source of information about iodized salt among the salt retailers was health workers (46.2\%), followed by a friend (16.7\%), school $(14.2 \%)$, radio (10.2\%), family member $(8.6 \%)$, and television (4.1\%) (Figure $1(\mathrm{a})$ ). About $49.7 \%$ and $56.9 \%$ of the retailers have low knowledge of the benefits of iodized salt use and the effects of iodine deficiency in humans, respectively. Generally, $47.2 \%$ of the retailers have high/good knowledge of iodized salt (Figure 1(b)).

3.3. Iodine Concentration Levels of Salts in Retail Shops. Less than half $(46.2 \%)$ of salts in retail shops in the district have satisfactory ( $\geq 15 \mathrm{ppm}$ ) iodine, $41.6 \%$ have inadequate iodine $(<15 \mathrm{ppm})$, and $12.2 \%$ do not have iodine $(0 \mathrm{ppm})$ (Figure 2).

3.4. Texture of Salt Type, How It Is Displayed for Sale, and Retailers' Knowledge on Iodine and Iodine Content. All the textures of salt type had different categories of iodine content. Fine-texture (4.0\%), coarse-texture (9.8\%), and granular-texture $(27.4 \%)$ have no iodine $(0 \mathrm{ppm})$, while granular-texture $(35.3 \%)$, coarse-texture $(43.7 \%)$, and finetexture $(56.0 \%)$ have adequate iodine $(\geq 15 \mathrm{ppm})$. Also, granular-texture $(37.3 \%)$, fine-texture $(40.0 \%)$, and coarsetexture $(46.5 \%)$ had some iodine but inadequate $(<15 \mathrm{ppm})$ to meet the recommended levels of $\geq 15 \mathrm{ppm}$.

Salt kept in the original package from the producer $(4.0 \%)$, in a handy polythene bag $(12.2 \%)$, in a large polythene bag $(14.3 \%)$, in an open container $(27.3 \%)$, placed under a shade (6.3\%), and placed directly in the sun (19.5\%) do not have iodine $(0 \mathrm{ppm})$. Also, salt kept in the original package from the producer $(56.8 \%)$, in a handy polythene bag (39.0\%), in a large polythene bag (46.9\%), in an open container $(30.3 \%)$, placed under a shade $(67.3 \%)$, and placed directly in the sun (19.5\%) have adequate iodine ( $\geq 15 \mathrm{ppm})$.

Retailers who have low knowledge on iodized salt were trading $19.2 \%$ of salt with no iodine $(0 \mathrm{ppm}), 46.2 \%$ of salt with inadequate iodine $(<15 \mathrm{ppm})$, and $34.6 \%$ of salt with adequate iodine $(\geq 15 \mathrm{ppm})$. Also, retailers who have high knowledge on iodized salt were selling $4.3 \%$ of salt with no iodine $(0 \mathrm{ppm}), 36.6 \%$ of salt with inadequate iodine $(<15 \mathrm{ppm})$, and $59.1 \%$ of salt with adequate iodine ( $\geq 15 \mathrm{ppm}$ ) (Table 2).
TABLE 1: Background characteristics of retailers.

\begin{tabular}{|c|c|c|}
\hline Variable & Frequency $(n=197)$ & Percentage \\
\hline \multicolumn{3}{|l|}{ Sex } \\
\hline Male & 72 & 36.5 \\
\hline Female & 125 & 63.5 \\
\hline \multicolumn{3}{|l|}{ Age group (years) } \\
\hline$<20$ & 41 & 20.8 \\
\hline $20-39$ & 63 & 32.0 \\
\hline$\geq 40$ & 93 & 47.2 \\
\hline \multicolumn{3}{|l|}{ Educational level } \\
\hline None & 89 & 45.2 \\
\hline Basic & 47 & 23.9 \\
\hline Secondary & 43 & 21.8 \\
\hline Tertiary & 18 & 9.1 \\
\hline \multicolumn{3}{|l|}{ Marital status } \\
\hline Single & 53 & 26.9 \\
\hline Married & 144 & 73.1 \\
\hline \multicolumn{3}{|l|}{ Type of marriage $(n=144)$} \\
\hline Monogamous & 81 & 56.3 \\
\hline Polygamous & 63 & 43.7 \\
\hline \multicolumn{3}{|l|}{ Ethnicity } \\
\hline Waala & 95 & 48.2 \\
\hline Sissala & 57 & 28.9 \\
\hline Dagaaba & 45 & 22.9 \\
\hline \multicolumn{3}{|l|}{ Religion } \\
\hline Christianity & 43 & 21.8 \\
\hline Islam & 154 & 78.2 \\
\hline \multicolumn{3}{|c|}{ Salt from wholesale shop tested for iodine } \\
\hline No & 195 & 99.0 \\
\hline Yes & 2 & 1.0 \\
\hline \multicolumn{3}{|l|}{ Texture of salt in shop } \\
\hline Fine & 75 & 38.1 \\
\hline Coarse & 71 & 36.0 \\
\hline Granular & 51 & 25.9 \\
\hline \multicolumn{3}{|c|}{ How salt was displayed for sale } \\
\hline In handy polythene bag & 41 & 20.8 \\
\hline In large polythene bag & 49 & 24.9 \\
\hline In original package & 74 & 37.6 \\
\hline Open/uncovered bowl & 33 & 16.7 \\
\hline \multicolumn{3}{|c|}{ Where salt was displayed for sale } \\
\hline Placed directly in sun & 87 & 44.2 \\
\hline Placed under shade & 110 & 55.8 \\
\hline
\end{tabular}

3.5. Factors Associated with Knowledge on Iodized Salt among Salt Retailers. The study showed significant associations between knowledge on iodized salt and retailer's sex ( $p=0.014)$, educational level $(p=0.006)$, primary source of information on iodized salt $(p=0.012)$, salt texture $(p=0.023)$, and where salt was displayed in the shop ( $p=0.003)$. Furthermore, when variables that were having associations with high knowledge on iodized salt from the bivariate analysis were tested for confounding effects using multiple logistic regression analysis, it showed that retailers who were females (AOR: 0.59, 95\% CI: 10.81-33.09, $p=0.011$ ) were less likely to have high knowledge of iodized salt than the retailers who were males. Again, retailers who attained basic education (AOR: 2.64, 95\% CI: 3.43-27.33, $p=0.005$ ), secondary education (AOR: $4.31,95 \% \mathrm{CI}$ : 6.64-35.41, $p=0.005$ ), and tertiary education (AOR: 9.24, 


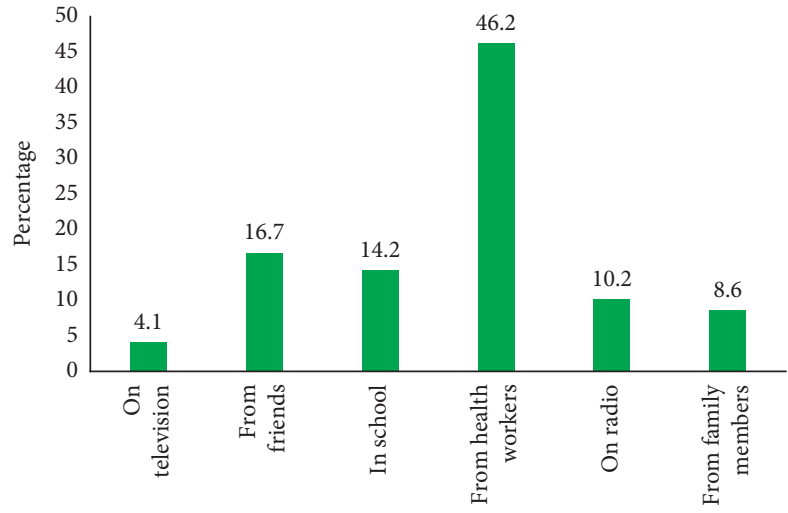

Source of information on iodized salt

(a)

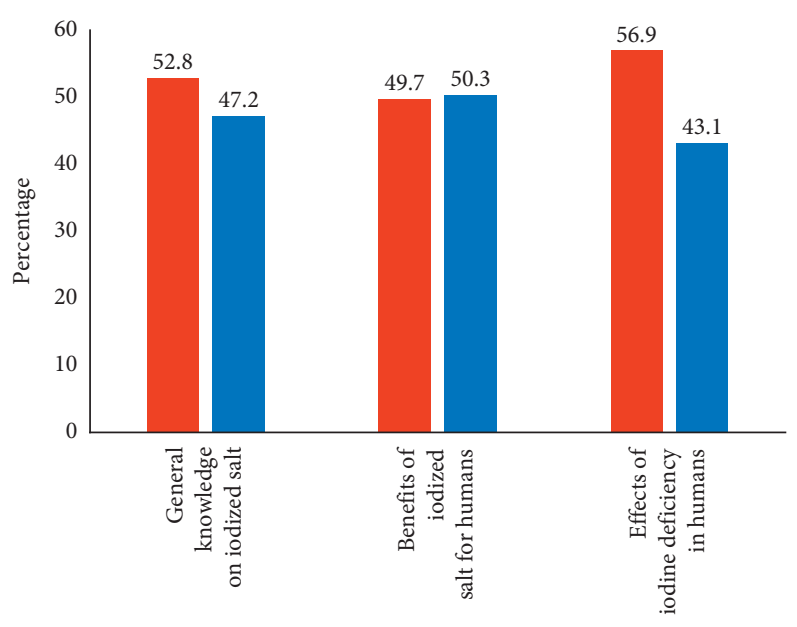

Knowledge on iodized salt

- Low knowledge

- High knowledge

(b)

FIGURE 1: (a) Retailers' primary source of information on iodized salt. (b) Retailers' knowledge on iodized salt.

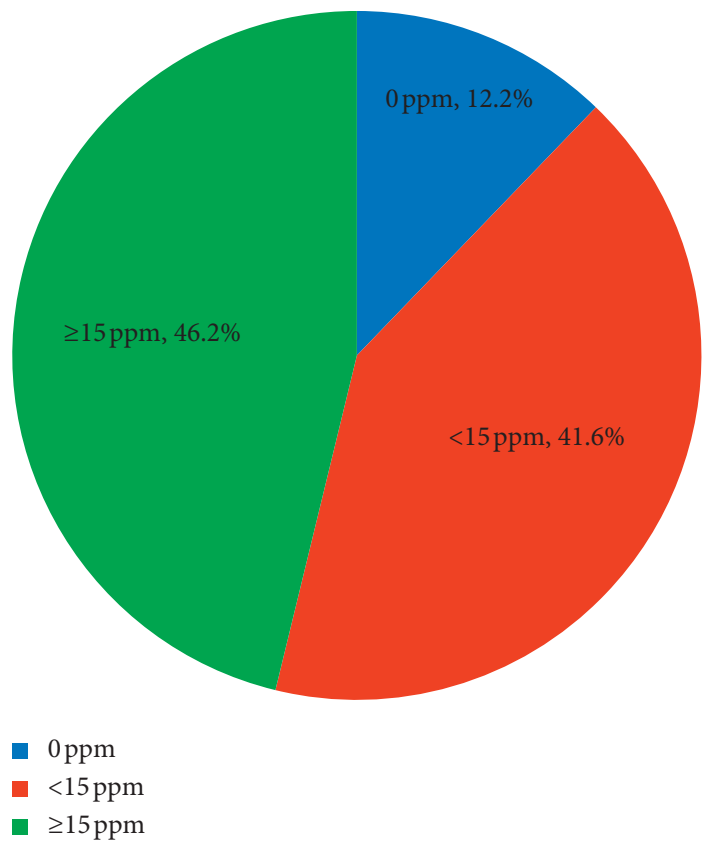

FIGURE 2: Iodine concentration levels of salts in retail shops.

95\% CI: 9.16-51.02, $p=0.006)$ were more likely to have high knowledge of iodized salt than retailers who did not go to school. Also, retailers who got information about iodized salt from the media (AOR: 0.59, 95\% CI: $1.03-8.43, p=0.019$ ) and friend/family member (AOR: $0.44,95 \%$ CI: $2.05-8.99$, $p=0.010$ were less likely to have high knowledge of iodized salt than those who got information about iodized salt from a health worker, while those who got information about iodized salt from the schools attended (AOR: 0.69, 95\% CI: 1.98-15.73, $p=0.011$ ) were more likely to have high knowledge of iodized salt than those who got information about iodized salt from a health worker. Again, retailers trading coarse-texture salt (AOR: 0.73, 95\% CI: 3.33-81.02, $p=0.014$ and granular-texture salt (AOR: 0.68, 95\% CI: 5.67-58.99, $p=0.028$ ) were less likely to have high knowledge of iodized salt than retailers who are trading finetexture salt, while retailers who placed salt under a shade (AOR: 6.24, 95\% CI: 10.03-79.65, $p=0.002$ ) were more likely to have high knowledge of iodized salt than retailers who placed salt directly in the sun (Table 3).

3.6. Factors Associated with Having Iodized Salt in the Retail Shop. The analysis showed significant associations between salt having iodine and educational level $(p=0.036)$, knowledge on iodized salt $(p=0.034)$, texture of salt $(p=0.021)$, and where salt was displayed for sale $(p=0.004)$. Additionally, when variables that had associations with adequate iodized salt from bivariate analysis were tested for confounding effects using multiple logistic regression analysis, it showed that retailers who attained basic education (AOR: 2.65, 95\% CI: 2.98-18.16, $p=0.038$ ), secondary education (AOR: 4.31, 95\% CI: 3.93-41.15, $p=0.029$ ), and tertiary education (AOR: 9.13, 95\% CI: 4.23-33.37, $p=0.026$ ) were more likely to have adequate iodized salt in their shops than retailers who did not go to school. Also, retailers who have low knowledge of iodized salt (AOR: 0.41, 95\% CI: 0.05-29.56, $p=0.032$ ) were less likely to have adequate iodized salt in their shops than those who have high knowledge of iodized salt. Again, coarsetexture salt (AOR: 0.49, 95\% CI: 3.89-31.27, $p=0.015$ ) and granular-texture salt (AOR: 0.42, 95\% CI: 7.78-48.13, $p=0.017)$ found in the shops were less likely to have adequate iodine than fine-texture salt found in the shops; salt placed under a shade (AOR: 7.24, 95\% CI: 11.03-68.42, $p=$ 0.002 was more likely to have adequate iodine than salt placed directly in the sun (Table 4 ). 
TABle 2: Texture of salt type, how it is displayed for sale, and retailers' knowledge on iodine and iodine content.

\begin{tabular}{|c|c|c|c|c|}
\hline \multirow{2}{*}{ Variable } & \multicolumn{4}{|c|}{ Levels of iodine in salt $(N=197)$} \\
\hline & No iodine $(0 \mathrm{ppm})$ & Inadequate iodine $(<15 \mathrm{ppm})$ & Adequate iodine ( $\geq 15 \mathrm{ppm})$ & Total \\
\hline Texture & $n(\%)$ & $n(\%)$ & $n(\%)$ & $n$ \\
\hline Fine & $3(4.0)$ & $30(40.0)$ & $42(56.0)$ & 75 \\
\hline Coarse & $7(9.8)$ & $33(46.5)$ & $31(43.7)$ & 71 \\
\hline Granular & $14(27.4)$ & $19(37.3)$ & $18(35.3)$ & 51 \\
\hline \multicolumn{5}{|c|}{ How salt was displayed in the shop } \\
\hline In handy polythene bag & $5(12.2)$ & $20(48.8)$ & $16(39.0)$ & 41 \\
\hline In large polythene bag & $7(14.3)$ & $19(38.8)$ & $23(46.9)$ & 49 \\
\hline In original package & $3(4.0)$ & $29(39.2)$ & $42(56.8)$ & 74 \\
\hline Open/uncovered bowl & $9(27.3)$ & $14(42.4)$ & $10(30.3)$ & 33 \\
\hline \multicolumn{5}{|c|}{ Where salt was displayed in the shop } \\
\hline Placed directly in sun & $17(19.5)$ & $53(61.0)$ & $17(19.5)$ & 87 \\
\hline Placed under shade & $7(6.3)$ & $29(26.4)$ & $74(67.3)$ & 110 \\
\hline \multicolumn{5}{|l|}{ Knowledge level on iodine } \\
\hline High (good) & $4(4.3)$ & $34(36.6)$ & $55(59.1)$ & 93 \\
\hline Low (poor) & $20(19.2)$ & $48(46.2)$ & $36(34.6)$ & 104 \\
\hline
\end{tabular}

TABLE 3: Factors associated with retailers' knowledge of iodized salt.

\begin{tabular}{|c|c|c|c|c|c|}
\hline \multirow{2}{*}{ Attributes } & \multicolumn{2}{|c|}{ Knowledge level } & \multirow{2}{*}{ COR (95\% CI); } & \multirow{2}{*}{$p$ value } & \multirow{2}{*}{ AOR (95\% CI); $p$ value } \\
\hline & Low (poor) $104(52.8 \%)$ & High (good) 93 (47.2\%) & & & \\
\hline \multicolumn{6}{|c|}{ 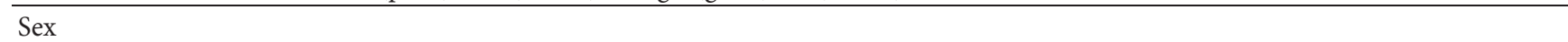 } \\
\hline Male & $13(18.1)$ & $59(81.9)$ & 1 & \multirow{2}{*}{0.014} & 1 \\
\hline Female & $91(72.8)$ & $34(27.2)$ & $0.68(7.79-30.27)$ & & $0.59(10.81-33.09) 0.011$ \\
\hline \multicolumn{6}{|l|}{ Age (years) } \\
\hline$<20$ & $12(29.3)$ & $29(70.7)$ & 1 & \multirow{3}{*}{0.454} & \\
\hline $20-39$ & $22(34.9)$ & $41(65.1)$ & $0.76(0.18-9.38)$ & & \\
\hline$\geq 40$ & $70(75.3)$ & $23(24.7)$ & $0.49(0.22-15.63)$ & & \\
\hline \multicolumn{6}{|l|}{ Educational level } \\
\hline None & $60(67.4)$ & $29(32.6)$ & 1 & \multirow{4}{*}{0.006} & 1 \\
\hline Basic & $27(57.4)$ & $20(42.6)$ & $2.76(11.48-45.23)$ & & $2.64(3.43-27.33) 0.005$ \\
\hline Secondary & $11(25.6)$ & $32(74.4)$ & $3.65(12.63-43.67)$ & & $9.31(6.64-35.41) 0.005$ \\
\hline Tertiary & $6(33.3)$ & $12(66.7)$ & $7.87(9.77-51.59)$ & & $4.24(9.16-51.02) 0.006$ \\
\hline \multicolumn{6}{|l|}{ Marital status } \\
\hline Single & $32(60.4)$ & $21(39.6)$ & 1 & \multirow{2}{*}{0.083} & \\
\hline Married & $72(50.0)$ & $72(50.0)$ & $0.67(0.37-1.20)$ & & \\
\hline \multicolumn{6}{|l|}{ Religion } \\
\hline Christianity & $10(23.3)$ & $33(76.7)$ & 1 & \multirow{2}{*}{0.310} & \\
\hline Islam & $94(61.0)$ & $60(39.0)$ & $0.53(0.01-3.71)$ & & \\
\hline \multicolumn{6}{|l|}{ Ethnicity } \\
\hline Waale & $74(77.9)$ & $21(22.1)$ & 1 & \multirow{3}{*}{0.069} & \\
\hline Sissala & $19(33.3)$ & $38(66.7)$ & $2.71(0.29-4.53)$ & & \\
\hline Dagaaba & $11(24.4)$ & $34(75.6)$ & $3.12(0.54-4.12)$ & & \\
\hline \multicolumn{6}{|c|}{ Primary source of information on iodized salt } \\
\hline Health worker & $44(48.4)$ & $47(51.6)$ & 1 & \multirow{4}{*}{0.012} & 1 \\
\hline Media & $16(57.1)$ & $12(42.9)$ & $0.62(1.01-7.11)$ & & $0.59(1.03-8.43) 0.019$ \\
\hline Friend/family & $31(62.0)$ & $19(38.0)$ & $0.49(1.64-9.07)$ & & $0.44(2.05-8.99) 0.010$ \\
\hline School attended & $13(46.4)$ & $15(53.6)$ & $0.78(2.12-13.92)$ & & $1.69(1.98-15.73) 0.011$ \\
\hline \multicolumn{6}{|l|}{ Texture of salt in the shop } \\
\hline Fine & $34(45.3)$ & $41(54.7)$ & 1 & \multirow{3}{*}{0.023} & 1 \\
\hline Coarse & $43(60.6)$ & $28(39.4)$ & $0.79(4.01-67.73)$ & & $0.73(3.33-81.02) 0.014$ \\
\hline Granular & $27(52.9)$ & $24(47.1)$ & $0.63(2.43-49.14)$ & & $0.68(5.67-58.99) 0.028$ \\
\hline \multicolumn{6}{|c|}{ How salt was displayed in the shop } \\
\hline In original package & $33(44.6)$ & $41(55.4)$ & 1 & \multirow{4}{*}{0.231} & \\
\hline In a handy poly bag & $22(53.7)$ & $19(46.3)$ & $0.47(0.25-5.76)$ & & \\
\hline In a large poly bag & $27(55.1)$ & $22(44.9)$ & $0.49(0.09-4.83)$ & & \\
\hline In an open container & $22(66.7)$ & $11(33.3)$ & $0.38(0.03-6.11)$ & & \\
\hline \multicolumn{6}{|c|}{ Where salt was displayed in the shop } \\
\hline Directly in the sun & $69(79.3)$ & $18(20.7)$ & 1 & \multirow[b]{2}{*}{0.003} & 1 \\
\hline Under shade & $35(31.8)$ & $75(68.2)$ & $5.76(10.74-82.76)$ & & $6.24(14.03-79.65) 0.002$ \\
\hline
\end{tabular}


TABLE 4: Factors associated with having iodized salt in the retail shop.

\begin{tabular}{|c|c|c|c|c|c|}
\hline \multirow{2}{*}{ Attribute } & \multicolumn{2}{|c|}{ Iodine content of salt } & \multirow{2}{*}{ COR $(95 \% \mathrm{CI})$} & \multirow{2}{*}{$p$ value } & \multirow{2}{*}{ AOR $(95 \% \mathrm{CI}) ; p$ value } \\
\hline & Inadequate $106(53.8 \%)$ & Adequate $91(46.2 \%)$ & & & \\
\hline \multicolumn{6}{|l|}{ Sex } \\
\hline Male & $34(47.2)$ & $38(52.8)$ & 1 & \multirow{2}{*}{0.322} & \\
\hline Female & $72(57.6)$ & $53(42.4)$ & $0.52(0.47-13.18)$ & & \\
\hline \multicolumn{6}{|l|}{ Age (years) } \\
\hline$<20$ & $20(48.8)$ & $21(51.2)$ & 1 & \multirow{3}{*}{0.363} & \\
\hline $20-39$ & $32(50.8)$ & $31(49.2)$ & $0.62(0.06-11.05)$ & & \\
\hline$\geq 40$ & $54(58.1)$ & $39(41.9)$ & $0.53(0.14-9.72)$ & & \\
\hline \multicolumn{6}{|l|}{ Educational level } \\
\hline None & $61(68.5)$ & $28(31.5)$ & 1 & \multirow{4}{*}{0.036} & 1 \\
\hline Basic & $24(51.1)$ & $23(48.9)$ & $2.29(2.84-9.17)$ & & $2.65(2.98-18.16) 0.038$ \\
\hline Secondary & $16(37.2)$ & $27(62.8)$ & $5.37(9.14-29.97)$ & & $4.31(3.93-41.15) 0.029$ \\
\hline Tertiary & $5(27.8)$ & $13(72.2)$ & $8.54(7.27-38.81)$ & & $9.13(4.23-33.37) 0.026$ \\
\hline \multicolumn{6}{|l|}{ Marital status } \\
\hline Single & $28(52.8)$ & $25(47.2)$ & 1 & \multirow{2}{*}{0.179} & \\
\hline Married & $78(54.2)$ & $66(45.8)$ & $0.67(0.07-12.39)$ & & \\
\hline \multicolumn{6}{|l|}{ Religion } \\
\hline Christianity & $14(32.6)$ & $29(67.4)$ & 1 & \multirow{2}{*}{0.398} & \\
\hline Islam & $92(59.7)$ & $62(40.3)$ & $0.61(0.38-9.22)$ & & \\
\hline \multicolumn{6}{|l|}{ Ethnicity } \\
\hline Waale & $66(69.5)$ & $29(30.5)$ & 1 & \multirow{3}{*}{0.077} & \\
\hline Sissala & $24(42.1)$ & $33(57.9)$ & $3.18(0.09-7.85)$ & & \\
\hline Dagaaba & $16(35.6)$ & $29(64.4)$ & $3.79(0.13-6.24)$ & & \\
\hline \multicolumn{6}{|c|}{ Primary source of information on iodized salt } \\
\hline Health worker & $45(49.5)$ & $46(50.5)$ & 1 & \multirow{4}{*}{0.068} & \\
\hline Media & $15(53.6)$ & $13(46.4)$ & $0.74(0.43-6.93)$ & & \\
\hline Friend/family & $35(70.0)$ & $15(30.0)$ & $0.43(0.16-7.02)$ & & \\
\hline School attended & $11(39.3)$ & $17(60.7)$ & $0.76(0.27-5.99)$ & & \\
\hline \multicolumn{6}{|l|}{ Knowledge level } \\
\hline High (good) & $32(34.4)$ & $61(65.6)$ & 1 & \multirow{2}{*}{0.034} & 1 \\
\hline Low (poor) & $74(71.2)$ & $30(28.8)$ & $0.46(0.09-23.42)$ & & $0.41(0.05-29.56) 0.032$ \\
\hline \multicolumn{6}{|l|}{ Texture of salt } \\
\hline Fine & $34(45.3)$ & $41(54.7)$ & 1 & \multirow{3}{*}{0.021} & 1 \\
\hline Coarse & $42(59.2)$ & $29(40.8)$ & $0.52(2.45-33.18)$ & & $0.49(3.89-31.27) 0.015$ \\
\hline Granular & $30(58.8)$ & $21(412)$ & $0.51(3.27-39.37)$ & & $0.42(7.78-48.13) 0.017$ \\
\hline \multicolumn{6}{|c|}{ How salt was displayed in the shop } \\
\hline In the original package & $24(33.8)$ & $49(66.2)$ & 1 & & \\
\hline In a handy poly bag & $26(63.4)$ & $15(36.6)$ & $0.69(0.34-8.27)$ & 0059 & \\
\hline In a large poly bag & $31(63.3)$ & $18(36.7)$ & $0.63(0.21-7.93)$ & 0.059 & \\
\hline In an open container & $24(72.7)$ & $9(27.3)$ & $0.49(0.16-9.02)$ & & \\
\hline Where salt was displayed & the shop & & & & \\
\hline Directly in the sun & $73(83.9)$ & $14(16.1)$ & 1 & & 1 \\
\hline Under shade & $33(30.0)$ & $77(70.0)$ & $6.58(8.65-56.23)$ & 0.004 & $7.24(11.03-68.42) 0.002$ \\
\hline
\end{tabular}

\section{Discussion}

One of the most common and effective public health approaches for the eradication of IDD globally is Universal Salt Iodization [10]. Currently, merely $47.2 \%$ of the salt retailers in Wa East District have excellent knowledge of iodized salt in contrary to comparable surveys carried out in the Gushegu District in the northern region and the Hohoe Municipality in the Volta Region [11, 12]. Although the present study involved salt retailers and not households, the exposures, including the Gushegu and Hohoe studies, were far beneath the results of recent Ghana's Demographic and Health Survey [5].

The primary source of information on iodized salt could affect an individual's knowledge of iodized salt and utilization of iodized salt $[13,14]$. This study showed that just $46.2 \%$ of salt retailers got information about iodized from a health professional; this agrees with Mahar et al.'s study in Pakistan which revealed that quantity and quality of information, education, and communication affect healthcare services utilization [15]. The lack of information about iodized salt from a health worker probably translated into 
$44.2 \%$ of the retailers displaying salt directly under the sun. However, this finding disagrees with the study in Ethiopia [16].

The number of retail shops trading adequate iodized salt $(\geq 15 \mathrm{ppm})$ in the district was not inspiring. Nevertheless, the result is above what was reported in the Volta region and Ghana's Multiple Indicator Cluster Surveys [6, 17] and below the finding of the Indian study [18]. Although the iodine concentration level of salt in retail shops in the district may be above other parts in Ghana, it is still scantily above half of the $90 \%$ target suggested by the WHO/UNICEF [19]. These differences might be due to challenges in the distribution chain and require policies and laws to promote production and sale of iodized salt to be revisited at and strengthened.

The district has more educated males than females [8]. Therefore, it is not unusual that females were less likely to have high knowledge of iodized salt than males. The finding agrees with studies in the northern parts of Ghana that indicated gender inequalities in education [20-23].

This study showed that retailers who placed salt under shade were more likely to have high knowledge of iodized salt than retailers who placed salt directly in the sun. However, direct exposure of iodized salt to the sun is known to reduce its iodine content [6]. The practices of placing salt directly in the sun could be avoided if the individual knows the effects of exposing iodized salt to the sun rays. Again, this study showed that retailers who attained basic, secondary, and tertiary education were more likely to have high knowledge of iodized salt than retailers who never went to school. Also, retailers who got information about iodized salt from a health worker were more likely to have good knowledge of iodized salt than retailers who got information about iodized salt from other sources. What these findings mean is that the quality of the information received and an improvement in an individual's education can influence his/ her knowledge of iodized salt. These findings agree with other studies elsewhere [13, 22-24].

Furthermore, this study exposed significant associations between iodine content of salt in retail shops and where retailers have displayed salt in their shops and indicated that salt placed directly in the sun was less likely to have adequate iodine than salt placed under shade. Meanwhile, salt is known to lose its iodine content when exposed to the sun rays [6], meaning salt with less iodine is being sold to households in the district. Also, retailers who attained some level school have a higher chance of selling iodized salt in conformity with the findings from the study conducted in the Laelay Maychew District in Northern Ethiopia [25]. Again, the texture of salt was shown to be associated with iodine content and agrees with the Volta region and Mthatha studies $[6,26]$, meaning iodized salt producers should factor salt texture in their production plans to ensure they produce salt texture that can hold iodine.

\section{Conclusion}

Although there are policies and programmes aimed at increasing iodized salt utilization in the country, the iodine content of salt in retail shops in the Wa East District is not up to the standards required in the country. Besides, salt retailers have low knowledge of iodized salt. The findings of the study indicate that salt with less iodine is being sold to households in the district and will also affect the outcome of any study to assess iodine concentrations of households' salt. Again, the outcome of the study shows that policies and programmes to promote production and utilization of iodized salt are not serving the intended goal. Hence, a review is required for strengthening these policies and programmes, if $>90 \%$ of households with adequate iodized salt is to be achieved. A holistic approach is needed to monitor the iodine content of salt along the supply chain.

\subsection{Recommendations}

(1) Iodized salt producers and distributors should establish steps to guarantee that the iodine content of salt produced is maintained throughout the supply chain

(2) Regulatory bodies, including the security agencies, food and drugs authority, and Ghana Standard Authority, should institute and implement iodine checkpoints along the distribution chain to ensure adequate iodized salt reaches the final consumer

(3) Ghana Health Service, in collaboration with other key stakeholders, should organize training for traders/retailers on proper ways to store and display salt for sale to avoid the loss of iodine

\section{Abbreviations}

WHO: World Health Organization

UNICEF: United Nations Children's Fund

PNDCL: Provisional National Defence Council Law

CBR: $\quad$ Crude birth rate

CHPS: Community-Based health planning and services

COR: Crude odds ratio

AOR: Adjusted odds ratio

PPM: $\quad$ Parts per million

IDD: Iodine-deficiency disorders.

\section{Data Availability}

The data used to support the findings of this study can be made available from the corresponding author upon request.

\section{Ethical Approval}

The study followed the required ethical guidelines regarding the use of human subjects and was reviewed and approved by the Ethics Review Committee of the University of Health and Allied Sciences in Ghana

\section{Consent}

The participation was strictly voluntary, and consent assent for participation was obtained from the study participants and guardians of those below 18 years. 


\section{Conflicts of Interest}

The authors declare that they have no conflicts of interest regarding the publication of this paper.

\section{Acknowledgments}

The authors express their appreciations to the Wa East District Director of Health Service for granting them the permission to carry out the study in his jurisdiction and also to all retailers for their cooperation and support through the study.

\section{References}

[1] Development Initiatives, 2018 Global Nutrition Report: Shining a Light to Spur Action on Nutrition, Development Initiatives, Bristol, UK, 2018.

[2] R. Doggui, M. E. Ati-Hellal, P. Traissac, and J. E. Ati, "Unsatisfactory results of the Tunisian universal salt iodization program on national iodine levels," Journal of Food Composition and Analysis, vol. 64, no. 2, pp. 163-170, 2017.

[3] M. E. Kamwaya and L. D. Akwilapo, "Quality of common salt in the Tanzanian market," Tanzania Journal of Engineering and Technology, vol. 28, no. 1, 2005.

[4] G. Egbi, "Prevalence of vitamin a, zinc, iodine deficiency and anaemia among 2-10 year-old Ghanaian children," African Journal of Food, Agriculture, Nutrition and Development, vol. 12, no. 2, pp. 5946-5958, 2012.

[5] Ghana Statistical Service (GSS), Ghana Health Service (GHS), and ICF International, Ghana Demographic and Health Survey 2014, GSS, GHS, and ICF International, Rockville, MD, USA, 2015.

[6] F. Agbozo, J. B. Der, N. J. Glover, and B. Ellahi, "Household and market survey on availability of adequately iodized salt in the Volta region, Ghana," International Journal of Health Promotion and Education, vol. 55, no. 3, pp. 110-122, 2017.

[7] G. N. Doku and E. A. Bortey, "Iodine levels in brands of salt on the markets of Accra, Ghana," Ghana Medical Journal, vol. 52, no. 3, pp. 163-167, 2018.

[8] Ghana Statistical Service, "2010 population and housing census report," District Analytical Report, Ghana Statistical Service, Accra, Ghana, 2014.

[9] GHS Annual Report, Ghana Health Service: Wa East Annual Report, 2019.

[10] WHO, UNICEF, ICCIDD, Recommended Iodine Levels in Salt and Guidelines for Monitoring Their Adequacy and Effectiveness, World Health Organization, Geneva, Switzerland, 1996, http://whqlibdoc.who.int/hq/1996/WHO_NUT_96.13. pdf.

[11] D. Chirawurah, S. Apanga, and J. Addah, "Assessing iodized salt use in rural Northern Ghana: a mixed method approach," Food and Public Health, vol. 5, no. 3, pp. 70-76, 2015.

[12] A. N. Sarah, K. A. Prince, S. A. Yao, A. A. Geoffrey, K. T. Wisdom, and K. Margaret, "Knowledge on iodized salt use and iodine content of salt among households in the Hohoe municipality, Volta region-Ghana," Central African Journal of Public Health, vol. 2, no. 1, pp. 1-10, 2016.

[13] K. Charlton, H. Yeatman, F. Houweling, and S. Guenon, "Urinary sodium excretion, dietary sources of sodium intake and knowledge and practices around salt use in a group of healthy Australian women," Australian and New Zealand Journal of Public Health, vol. 34, no. 4, pp. 356-363, 2010.
[14] L. Mehran, P. Nazeri, H. Delshad, P. Mirmiran, Y. Mehrabi, and F. Azizi, "Does a text messaging intervention improve knowledge, attitudes and practice regarding iodine deficiency and iodized salt consumption?" Public Health Nutrition, vol. 15, no. 12, pp. 2320-2325, 2012.

[15] B. Mahar, R. Kumar, N. Rizvi, H. A. Bahalkani, M. Haq, and J. Soomro, "Quantity and quality of information, education and communication during antenatal visit at private and public sector hospitals of Bahawalpur, Pakistan," Journal of Ayub Medical College Abbottabad, vol. 24, no. 3-4, pp. 71-74, 2012.

[16] M. M. Bazezew, W. W. Yallew, and A. K. Belew, "Knowledge and practice of iodized salt utilization among reproductive women in Addis Ababa City," BMC Research Notes, vol. 11, no. 1, p. 734, 2018.

[17] Ghana Statistical Service, Multiple Indicator Cluster Survey, 2011: Monitoring the Situation of Children, Women, and Men; with an Enhanced Malaria Module and Biomarker, Ghana Statistical Service, Accra, Ghana, 2011.

[18] R. Srivastava, K. Yadav, R. P. Upadhyay et al., "Iodized salt at households and retail shops in a rural community of Northern India," South East Asia Journal of Public Health, vol. 2, no. 1, pp. 18-23, 2012.

[19] UNICEF, The State of the World's Children 2014 in Numbers: Every Child Counts, UNICEF, New York, NY, USA, 2014.

[20] B. Senadza, "Education inequality in Ghana: gender and spatial dimensions," Journal of Economic Studies, vol. 39, no. 6, pp. 724-739, 2012.

[21] M. Lambert, E. S. Perrino, and E. M. Barreras, Understanding the Barriers to Female Education in Ghana, Blue Kitabu Research Institute, 2012.

[22] P. Mirmiran, P. Nazeri, P. Amiri, L. Mehran, N. Shakeri, and F. Azizi, "Iodine nutrition status and knowledge, attitude, and behavior in Tehranian women following 2 decades without public education," Journal of Nutrition Education and Behavior, vol. 45, no. 5, pp. 412-419, 2013.

[23] K. E. Charlton, L. Gemming, H. Yeatman, and G. Ma, "Suboptimal iodine status of Australian pregnant women reflects poor knowledge and practices related to iodine nutrition," Nutrition, vol. 26, no. 10, pp. 963-968, 2010.

[24] M. Girma, E. Loha, A. Bogale, N. Teyikie, C. Abuye, and B. J. Stoecker, "Iodine deficiency in primary school children and knowledge of iodine deficiency and iodized salt among caretakers in Hawassa town: Southern Ethiopia," Ethiopian Journal of Health Development, vol. 26, no. 1, pp. 30-35, 2012.

[25] B. Gidey, K. Alemu, A. Atnafu, M. Kifle, Y. Y. Tefera, and H. R. Sharma, "Availability of adequate iodized salt at household level and associated factors in rural communities in Laelay Maychew district, Northern Ethiopia: a cross sectional study," Journal of Nutrition and Health Sciences, vol. 2, no. 1, p. 1, 2015.

[26] G. Mandisa, G. George, Benjamin, and L.-M. Benjamin, "Iodine content of iodized salt available in retail outlets in Mthatha," African Journal of Food Science, vol. 4, no. 8, pp. 486-494, 2010. 